International Journal of Agriculture, Environment and Bioresearch

Vol. 5, No. 04; 2020

ISSN: $2456-8643$

\title{
GROWTH ANALYSIS OF GRASS MULATO II (HYBRID Urochloa) BY VARIETY OF CUTTING INTENSITY
}

\author{
Adelaido Rafael Rojas García ${ }^{1}$, María de los Ángeles Maldonado Peralta ${ }^{*}$, Paulino Sánchez Santillán1, \\ Filiberto Magadan Olmedo1, Perpetuo Álvarez Vazquez ${ }^{2}$, Marco Antonio Rivas Jacobo ${ }^{3}$ \\ 1Universidad Autónoma de Guerrero, Facultad de Medicina Veterinaria y Zootecnia No 2. Cuajinicuilapa, Guerrero, \\ México \\ 2Departamento de Recursos Naturales Renovables-UAAAN. Calzada Antonio Narro 1923, Buenavista, Saltillo, \\ Coahuila. CP. 25315. \\ 3Facultad de Agronomía y Veterinaria de la UASLP. Carretera San Luis-Matehuala km 14.5, Ejido Palmade la Cruz, \\ Soledad de Graciano Sánchez, San Luis Potosí. CP. 78321
}

https://doi.org/10.35410/IJAEB.2020.5523

\begin{abstract}
The objective was to evaluate an analysis of growth of grass Mulato II (hybrid Urochloa) by varying the intensity and obtaining the optimal cutting moment in the dry and rainy season. The evaluated variables were: forage yield, morphological composition, plant density, plant height and intercepted relationship. The best dry matter yieldwas obtained at 56 days in rain, at an intensity of $15 \mathrm{~cm}, 1,820 \mathrm{~kg}$ DM ha-1andthe lowest at 7 days of regrowth in the dry season, with intensity $10 \mathrm{~cm}$ and a yield of $200 \mathrm{~kg}$ DM ha-1. The highest plant density was in the dry season and lowest in rain with 9.5 and 8.5 plants $\mathrm{m}-2$, respectively. $95 \%$ of intercepted radiation was obtained at $70 \mathrm{~cm}$ of plant height, in the rainy season, at $15 \mathrm{~cm}$ of cutting intensity and with 42 days of regrowth. The grass Mulato II should be cut between 35 and 42 days after the regrowth, at an intensity of $15 \mathrm{~cm}$, since that is when the best structural characteristics and the highest intercepted radiation are found $(95 \%)$.
\end{abstract}

Keywords: Urochloa, forage accumulation, cutting intensity.

\section{INTRODUCTION}

Forage production is important since they are the most economical and sustainable source in livestock units and a fundamental part of ruminant feeding (Pérez et al. 2002). The mismanagement and low nutritional value of forage grasses in tropical and subtropical regions represents a limitation in the productivity of grazing ruminants, due to the high content of cell walls and the low concentration of crude protein, these variables affect the digestibility and consumption (Lara et al. 2009).

Beltrán et al. (2005) mention that the impact of forage quality is determined by the quantity and type of tissue removed, remaining leaf area, cutting frequency and physiological state of the plants. Prairie management modifies the adaptation, productive potential, and persistence of forage species (Hernández et al. 2012; Rojas et al. 2016). Cut frequency and intensity are two 
components of forage management strategies that determine yield and quality (Cruz et al. 2011; Rojas et al. 2018; Maldonado et al. 2019).

Several studies in tropical Mexico found in Brachiaria hybrid Mulato higher annual yieldwhen increasing frequency and intensity of grazing 12,309 $\mathrm{kg} \mathrm{DM} \mathrm{ha}^{-1}$, independently of the time of year, however,decreased crude protein with $88 \mathrm{~g} \mathrm{~kg}^{-1} \mathrm{DM}$ (Cruz et al. 2017a). In grass Brachiaria humidicola cv. Chetumal Cruz et al. (2017b) report the highest forage accumulation, grazing at a light intensity of $13-15 \mathrm{~cm}$ in height and a frequency of 28 days. Rojas et al. (2018) reported for the dry tropics in grass Cobra (hyrid Urochloa) the higher yield of dry matter at 56

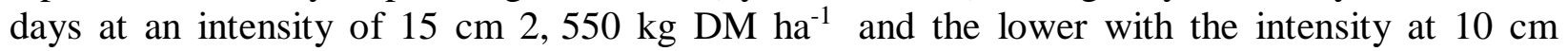
reaching a yield of $2,250 \mathrm{~kg} \mathrm{DM} \mathrm{ha}{ }^{-1}(\mathrm{p}=0.05)$.

In Mexico there are few research on yield accumulation and structural characteristics of grasses in the dry tropics. The objective of the present investigation was to evaluate an analysis of growth in Mulato II cv (Brachiaria now hybrid Urochloa) by varying the frequency and intensity and determine the optimal cutting time in the dry and rainy season.

\section{MATERIALS AND METHODS}

Location of the experimental area: The test was made from January to March and August to October 2017 at the experimental plots of the Facultad de Medicina Veterinaria No. 2 de la Universidad Autónoma de Guerrero, situated in Cuajinicuilapa, Guerrero, Mexico. Located at coordinates $16^{\circ} 28^{\prime} 28^{\prime \prime}$ north latitude and $98^{\circ} 25^{\prime} 11.27^{\prime \prime}$ west longitude at 46 masl. The climate is classified Aw and called the dry tropic according to the Köppen-Geiger system classification (García, 2004). The soil with a sandy clay texture, $\mathrm{pH} 4.8$ to 5.0, deficient in organic matter. The average annual temperature of the dry season, which comprises from January to March, was $26.9^{\circ} \mathrm{C}$ with a precipitation of $15 \mathrm{~mm}$, however, in the rainy season from August to October, the highest precipitation was recorded with $699 \mathrm{~mm}$ (Table 1). Gravity irrigations up to field capacity for regrowth recovery were applied every eight days in the dry season and fertilization was not applied throughout the experimental period. Climatic data were obtained from the agro-meteorological station CONAGUA located $1000 \mathrm{~m}$ of the experimental plots.

Table 1. Data maximum temperature, minimum, average $\left({ }^{\circ} \mathrm{C}\right)$ and precipitation $(\mathrm{mm})$ during the study period 2017.

\begin{tabular}{|cccccc|}
\hline Month & Maximum & Minimum & Half & Precipitation & Irrigation \\
\hline & \multicolumn{7}{c}{ Dry season } \\
\hline January & 35 & 19 & 27 & 8 & Yes \\
February & 35.5 & 19.5 & 27.5 & 4 & Yes \\
March & 36.6 & 19.8 & 28.5 & 3 & Yes \\
& & \multicolumn{2}{c}{ Rainy season } & & Not \\
August & 33 & 17 & 25 & 250 &
\end{tabular}


Vol. 5, No. 04; 2020

ISSN: $2456-8643$

$\begin{array}{cccccc}\text { September } & 32.5 & 17.5 & 25.5 & 280 & \text { Not } \\ \text { October } & 34.6 & 17.8 & 26.5 & 169 & \text { Not }\end{array}$

Plots management: The sowing of hybrid Urochloa cv Mulato II (CIAT 36087) was carried out on October 10, 2016 with a density of $8 \mathrm{~kg} \mathrm{ha}^{-1}$ of viable pure seed. The furrows were made with a separation of $50 \mathrm{~cm}$ and $5 \mathrm{~cm}$ between plants, agrochemicals were not applied throughout the experimental period. Three $10 \times 10 \mathrm{~m}$ plots were sown as experimental units. Likewise, each experimental unit was divided into two areas of $5 \times 10 \mathrm{~m}$ to evaluate two cutting intensities of 10 and $15 \mathrm{~cm}$ and these in turn into nine areas, in order to evaluate a growth analysis with nine ages of regrowth. The variables evaluated were: dry matter yield, morphology composition, plants $\mathrm{m}^{-}$ ${ }^{2}$, height of plant, intercepted radiation in the dry season and rain. Before starting the growth analysis, a homogenization cut was made at a height of 10 and $15 \mathrm{~cm}$ depending on the cutting intensity.

Variables evaluated

Yield of dry matter: After the uniformization cut every seven days, two 50 x $50 \mathrm{~cm}$ squares were cut in each experimental plot at 10 and $15 \mathrm{~cm}$ depending on the cutting intensity, selected randomly; the harvested forage was washed, and deposited in a forced air oven at $55{ }^{\circ} \mathrm{C}$ until constant weight to estimate recording the weight of dry matter per hectare, for different ages cutting.

Morphological composition: Of the samples for dry matter yield, approximately $20 \%$ was taken to evaluate the morphological and botanical composition, separating the leaf, stem, dead material and spike components. Subsequently each component was deposited in labeled paper bags and deposited in a forced air stove at $55^{\circ} \mathrm{C}$ until the samples obtained constant weight and the weight was recorded.

Plant density: A starting the experiment, a fixed box of $1 \mathrm{~m}^{-2}$ randomly in each experimental plot, one day latereach cut was counted the number of plants present and and with it, the average was obtained from plants by frequency, intensity and season of year.

Plant height: The average height per plant was estimated, a day before the cutting, taking randomly 20 readings at each experimental plot. For it, a $100 \mathrm{~cm}$ graduated ruler was used and the height was taken into account in the morphological component with the highest height.

Intercepted radiation:One day before each cut, five repetition radiation readings were taken at random with the wooden meter method described by Rojas et al. (2016) in each experimental unit. The readings were made at approximately 1:00 p.m. The procedure consisted of placing the ruler on the ground surface (under the canopy), facing south-north, and immediately afterwards, the shaded centimeters were counted, which represented the percentage of intercepted radiation by the vegetal canopy.

Statistical analysis: The data was analyzed using a completely randomized block design with arrangement in divided plots and three replications, the procedure used was PROC GLM from SAS (2011), where the effects of frequency and height of cut were considered as fixed. The multiple comparison of measure of the treatments was carried out using the Tukey test $(\alpha=0.05)$. 


\section{RESULTS AND DISCUSSION}

\section{Yield and morphological composition}

Growth analyzes of the grass Mulato II by varying the intensity of cut 10 and $15 \mathrm{~cm}$ during the dry and rain in Figure 1. Growth is observed as the age of regrowth increases until it reaches a maximum point and then decrease. The highest yield of dry matter was obtained at 56 days in the rainy season at an intensity of $15 \mathrm{~cm}$ with $1,820 \mathrm{~kg} \mathrm{DM} \mathrm{ha}^{-1}$ and the lower after 7 days of regrowth in the dry season with the intensity $10 \mathrm{~cm}$ with a yield of $200 \mathrm{~kg} \mathrm{DM} \mathrm{ha}^{-1}(\mathrm{P} \leq 0.05)$.

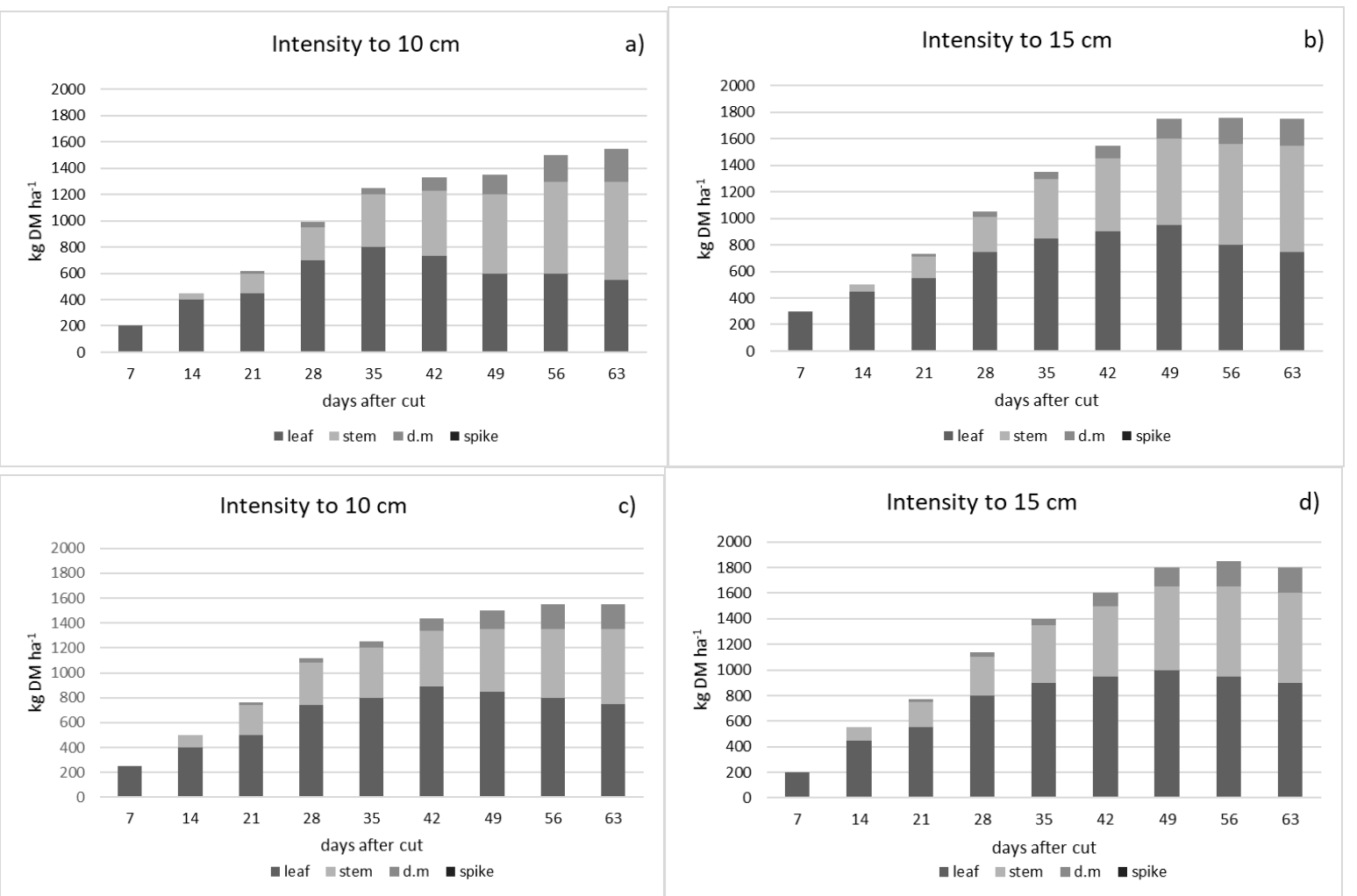

Figure 1. Total dry matter accumulation, and morphological composition of Mulato II grass (hybrid Urochloa) by varying the frequency (days) and cutting intensity $(\mathrm{cm})$ in the dry and rainy season; $\mathrm{m} . \mathrm{m} .=$ dead material; $\mathrm{a}$ and $\mathrm{b}=\mathrm{dry} ; \mathrm{c}$ and $\mathrm{d}=$ rain

The highest proportion of leaf was reported 35 days in intensity at $15 \mathrm{~cm}$ in the rainy season where it was increasing until it reached the maximum point with $1000 \mathrm{~kg} \mathrm{DM} \mathrm{ha}^{-1}$ (Figure 1; $\mathrm{P} \leq$ $0.05)$, and later begin to decline as the leaves in the lower layers were disappearing as indicated by Calzada et al. (2014), Rojas et al. (2018) and Maldonado et al. (2019) in tropical grasses. They report higher senescence at higher cutting frequency because they are below the light compensation point until the leaves continuously die.

Velasco et al. (2001), Rueda et al. (2016) and Wilson et al.(2017) report similar behavior in growth analysis of different grasses where the highest yield is obtained in the sixth week of regrowth, tending to decrease. The higher yield reported with an intensity of 
$15 \mathrm{~cm}$ could be due to the fact that there is a larger remaining leaf area which causes the biomass to recover more easily (Cruz et al. 2017a; Rojas et al. 2018), maintains higher reserves of carbohydrates, increases the persistence of the prairie and prevents soil erosion (Rojas et al. 2016). Rojas et al. (2018) when evaluating Cobra grass (hybrid Urochloa) obtained the highest dry matter yield at 56 days at an intensity of $15 \mathrm{~cm}$ with $2550 \mathrm{~kg} \mathrm{DM} \mathrm{ha}{ }^{-1}$, related to this investigation.

Independently of the frequency, intensity and time of the year the number of stem was in increasing as passed the evaluation time until the last week of evaluation at day 63 with $710 \mathrm{~kg}$ DM ha-1 $(\mathrm{P} \leq 0.05)$. The contribution of spike and dead material was minimal and was found in a higher proportion from day 42 with an average of $221 \mathrm{~kg} \mathrm{DM} \mathrm{ha}^{-1}$. Rojas et al. (2016) and Maldonado et al. (2019) found that the distribution of the components in the yield is influenced by the time of the year, planting density, associations and monoculture. On the other hand, different authors (Juskiw et al. 2000) mention that in the advanced stages the weight of the stem and spike increases, decreasing the leaf, which is explained physiologically by increasing the weight of the spike by filling grains, due in part translocation of nutrients from the leaves resulting in senescence and death of this component.

Plant density

Plant density $\mathrm{m}^{-2}$ of the grass Mulato II by varying the frequency and intensity of cutin the dry and rainy season it is observed in Table 2 . The highest plant density was reported in the intensity of $15 \mathrm{~cm}$ with an average 10 plants $\mathrm{m}^{-2}$ and lowest with an intensity of $10 \mathrm{~cm}$ in the rainy season with 8 plants $\mathrm{m}^{-2}(\mathrm{P}=0.05)$. In the time that the investigation lasted, was lost 1 floor $\mathrm{m}^{-2}$ in two intensities. This is due as time passing they go losing vigor and death of plants for the management given, since to higher intensity higher loss of plants (Rojas et al. 201 6).

Table 2. Density of plants $\left(\mathrm{m}^{-2}\right)$ of grass Mulato II (hybrid Urochloa) when varying the frequency (days) the height $(\mathrm{cm})$ of cut in the dry and rainy season.

\begin{tabular}{|c|c|c|c|c|c|c|c|c|c|}
\hline \multirow{2}{*}{$\begin{array}{l}\text { Intensity } \\
\text { (cm) }\end{array}$} & \multicolumn{9}{|c|}{ Cutting frequency (days) } \\
\hline & \multicolumn{9}{|c|}{ Dry season } \\
\hline & 7 & 14 & 21 & 28 & 35 & 42 & 49 & 56 & 63 \\
\hline 10 & $10 \mathrm{a}$ & $10 \mathrm{a}$ & $10 \mathrm{a}$ & $9 b$ & $9 b$ & $9 b$ & $9 b$ & $9 b$ & $9 b$ \\
\hline \multirow[t]{2}{*}{15} & $10 \mathrm{a}$ & $10 \mathrm{a}$ & $10 \mathrm{a}$ & $10 \mathrm{a}$ & $9 b$ & $9 b$ & $9 b$ & $9 b$ & $9 b$ \\
\hline & \multicolumn{9}{|c|}{ Rainy season } \\
\hline 10 & $9 a$ & $9 \mathrm{a}$ & $9 a$ & $9 \mathrm{a}$ & $8 b$ & $8 b$ & $8 \mathrm{~b}$ & $8 b$ & $8 b$ \\
\hline
\end{tabular}


Vol. 5, No. 04; 2020

ISSN: $2456-8643$

$\begin{array}{llllllllll}15 & 9 \mathrm{a} & 9 \mathrm{a} & 9 \mathrm{a} & 9 \mathrm{a} & 8 \mathrm{~b} & 8 \mathrm{~b} & 8 \mathrm{~b} & 8 \mathrm{~b} & 8 \mathrm{~b}\end{array}$

$a b c=$ Averages with the same lowercase literal in the same row, are not different $(\mathrm{P}=0.05)$.

The highest intensity of Mulato II grass plants with an intensity of $15 \mathrm{~cm}$ coincides with the highest contribution of forage yield at both times of the year (Table2; Figure 1). Sevilla et al. (2001) mention that, the death of plants is higher when there is higher grazing intensity, reaching the density of plants to be maintained in a certain time;noting that the minimum density required to not affect its growth is 30 plants per $\mathrm{m}^{-2}$, below which, prairie markedly decreases the production of forage. In this investigation we have by below this number of plants may be due to the species, type of growth and adaptation to the pedo-agronomical surrounding medium.

These changes in plant density are reflected in the crop of dry matter yield and are attributed to the height of cut (Figure 1) by its direct influence on photosynthesis (McKenzie et al. 1999) by having little remaining leaf area at the intensity of $10 \mathrm{~cm}$. In this regard, Chapman and Lemaire (1993) mention that the prairies respond differently to the management that is practiced, affecting their persistence and yieldby effect of intensity and interval of harvest. In this particular investigation the Mulato II grass was benefited by the management provided with the intensity at $15 \mathrm{~cm}$.

Plant height

Table 3 shows the height of the M ulato II grassby varying the frequency and intensity of cut in dry and rainy season. Independently of the cutting intensity and time of year, the height increased as the evaluation period passed $(\mathrm{P}=0.05)$. The highest plant height was $77 \mathrm{~cm}$, reported with a frequency of 49 days in the rainy season and with a residual area height of $15 \mathrm{~cm}$ $(\mathrm{P}=0.05)$. While the lowest height was reported in the intensity of $10 \mathrm{~cm}$ with $13 \mathrm{~cm}$ height at seven days of regrowth $(\mathrm{P}=0.05)$.

Table 3. Height (cm) of Mulato II grass (hybrid Urochloa) when varying the frequency (days) and height $(\mathrm{cm})$ of cut in the dry and rainy season.

\begin{tabular}{|c|c|c|c|c|c|c|c|c|c|}
\hline \multirow{3}{*}{$\begin{array}{l}\text { Intensity } \\
\text { (cm) }\end{array}$} & \multicolumn{9}{|c|}{ Cutting frequency (days) } \\
\hline & \multicolumn{9}{|c|}{ Dry season } \\
\hline & 7 & 14 & 21 & 28 & 35 & 42 & 49 & 56 & 63 \\
\hline 10 & $13 \mathrm{c}$ & $14 \mathrm{c}$ & $16 \mathrm{c}$ & $32 b$ & $39 \mathrm{~b}$ & $53 \mathrm{~b}$ & $69 a$ & $60 \mathrm{a}$ & $62 \mathrm{a}$ \\
\hline 15 & $17 \mathrm{c}$ & $20 \mathrm{c}$ & $25 \mathrm{~b}$ & $38 b$ & $45 b$ & $66^{\mathrm{a}}$ & $75 \mathrm{a}$ & $72 \mathrm{a}$ & $73 \mathrm{a}$ \\
\hline & \multicolumn{9}{|c|}{ Rainy season } \\
\hline
\end{tabular}


Vol. 5, No. 04; 2020

ISSN: $2456-8643$

$\begin{array}{llllllllll}10 & 13 \mathrm{c} & 15 \mathrm{c} & 18 \mathrm{~b} & 30 \mathrm{~b} & 41 \mathrm{~b} & 60^{\mathrm{a}} & 70 \mathrm{a} & 66 \mathrm{a} & 68 \mathrm{a} \\ 15 & 17 \mathrm{c} & 20 \mathrm{c} & 24 \mathrm{c} & 35 \mathrm{~b} & 45 \mathrm{~b} & 70 \mathrm{ab} & 77 \mathrm{a} & 74 \mathrm{a} & 75 \mathrm{a}\end{array}$

$a b c=$ Averages with the same lowercase literal in the same row, are not different $(p=0.05)$.

Changes in seasonal values obtained in plant height were closely related to annual yield; As height increases, yield increases (Figure 1). Similar results in tropical grasses were obtained by Maldonado et al. (2019) reported an increase in height coupled with a higher yield of dry matter and intercepted radiation up to a certain point to start declining. On the other hand, Velasco et al. (2005) and Castro et al. (2013) observed statistical differences between stations and frequencies, registering the highest height in summer and the lowest in winter. Intercepted radiation

Table 4 shows the intercepted radiation of the grass Mulato II by varying the frequency and intensity of cut in the dry and rainy season. As the cutting frequency increases, the intercepted radiation increases. The highest radiation was reported in the frequency of 63 days and with a height of $15 \mathrm{~cm}$ with $99 \%$ of radiation intercepted; however, it should be noted that in that week the quality of the stem and dead material increases, decreasing the quality (Figure 1). Where it is recommended to harvest the forage is when it reaches $95 \%$ of intercepted radiation and in this case it was in the rainy season 56 days after cutting with a cutting intensity of $15 \mathrm{~cm}$.

Table 4. Intercepted radiation (\%) of Mulato II grass (hybrid Urochloa) by varying the cutting frequency (days) and height $(\mathrm{cm})$ in the dry and rainy season.

\begin{tabular}{|c|c|c|c|c|c|c|c|c|c|}
\hline \multirow{2}{*}{$\begin{array}{l}\text { Intensity } \\
\text { (cm) }\end{array}$} & \multicolumn{9}{|c|}{ Cutting frequency (days) } \\
\hline & \multicolumn{9}{|c|}{ Dry season } \\
\hline & 7 & 14 & 21 & 28 & 35 & 42 & 49 & 56 & 63 \\
\hline 10 & $15 \mathrm{~d}$ & $18 \mathrm{~d}$ & $22 c$ & $35 c$ & $55 \mathrm{~b}$ & $77 \mathrm{~b}$ & $88 \mathrm{a}$ & $85 a$ & $80 \mathrm{a}$ \\
\hline 15 & $20 d$ & $25 \mathrm{~d}$ & $30 \mathrm{c}$ & $35 c$ & $60 \mathrm{~b}$ & $92 b$ & $93 \mathrm{a}$ & $94 a$ & $97 \mathrm{a}$ \\
\hline & \multicolumn{9}{|c|}{ Rainy season } \\
\hline 10 & $17 \mathrm{~d}$ & $30 \mathrm{~d}$ & $35 c$ & $56 c$ & $70 \mathrm{~b}$ & $90 \mathrm{~b}$ & $92 \mathrm{a}$ & $92 \mathrm{a}$ & $91 \mathrm{a}$ \\
\hline 15 & $21 d$ & $32 d$ & $36 c$ & $60 \mathrm{c}$ & $81 \mathrm{~b}$ & $95 b$ & $97 \mathrm{a}$ & $97 a$ & $99 a$ \\
\hline
\end{tabular}


$a b c=$ Averages with the same lowercase literal in the same row, are not different $(p=0.05)$.

In this regard, Da Silva and Nascimento (2007), Da Silva and Hernández-Garay (2010) and Maldonado et al. (2019) mention that forage should be harvested when it reaches $95 \%$ of intercepted radiation since the largest number of green leaves is found; these results are achieved when the plant density is competitive (Mattera et al. 2013; Rojas et al. 2016). The preceding percentages reveal that the ability of the species to interpret solar radiation depends on the number of plants, frequency, intensity and the environmental conditions to which they were exposed during their growth prior to each harvest (Federick et al. 1999; Horrocks and Vallentine, 1999; Da silva and Hernández-Garay, 2010).

\section{CONCLUSION}

As the re-growth increased, the dry matter yield increased until day 63, however, where the largest amount of leaf is found was on day 35. The height of the plant and intercepted radiation was increasing as the regrowth of the plant increased. However, the plant density was decreasing with the evaluation time.

Mulatto grass II should be cut 35 to 42 days after regrowth and at an intensity of $15 \mathrm{~cm}$, since it is when the best structural characteristics and $95 \%$ of intercepted radiation are found. It is recommended to continue expanding research on this tropical grass with more evaluation time and broaden the decision landscape.

\section{Acknowledgements}

The company Semillas Papalotla SA de CV and Dr. Álvaro Bernal Flores are thanked for donating the seed.

\section{REFERENCES}

Beltrán L. S., G. A. Hernández, M. E. García, P. J. Pérez, S. J. Kohashi, H. J. G. Herrera, C. A. R. Quero y M. S. S. González (2005) Efecto de la altura y frecuencia de corte en el crecimiento y rendimiento del pasto buffel (Cenchrus ciliaris 1.) en un invernadero. Agrociencia 39: 137147.https://www.colpos.mx/agrocien/Bimestral/2005/mar-abr/art-2.pdf

Calzada M. J. M., Q. J. F. Enríquez, G. A. Hernández, J. E. Ortega y P. S. I. Mendoza (2014) Análisis de crecimiento del pasto maralfalfa (Pennisetum sp.) en clima cálido subhúmedo. $\begin{array}{lllllll}\text { Revista } & \text { Mexicana de }\end{array}$ 260.http://www.scielo.org.mx/pdf/rmcp/v5n2/v5n2a9.pdf

Castro R. R., A. Hernández-Garay, R. O. Ramírez, B. G. Aguilar, Q. J. F. Enríquez y P. S. I. Mendoza (2013) Crecimiento en longitud foliar y dinámica de población de tallos de cinco asociaciones de gramíneas y leguminosa bajo pastoreo. Revista Mexicana de Ciencias Pecuarias 4 (2): 201-215.

http://www.scielo.org.mx/pdf/rmcp/v4n2/v4n2a6.pdf

Chapman D. F. and G. Lemaire (1993) Morphogenetic and structural determinants of plant regrowth after defoliation. Proceedings of the XVII International Grassland Congress. New Zealand and Australia p. 95-104. 
Cruz H. A., G. A. Hernández, I. E. Aranda, C. A. J. Chay, Q. C. Márquez, G. A. R. Rojas y V. A. Gómez (2017a) Nutritive value of Mulato grass under different grazing strategies. Ecosistemas y Recursos Agropecuarios 4 (10): 65-72. http://www.redalyc.org/pdf/3586/358649676007.pdf

Cruz H. A., G. A. Hernández, C. A. J. Chay, P. S. I. Mendoza, V. S. Ramírez, G. A. R. Rojas y R. J. Ventura (2017b)Componentes del rendimiento y valor nutritivo de Brachiaria humidicola cv Chetumal a diferentes estrategias de pastoreo. Revista Mexicana de Ciencias Agrícolas 8 (3): 599-610.

http://www.scielo.org.mx/pdf/remexca/v8n3/2007-0934-remexca-8-03-599.pdf

Cruz H. A., G. A. Hernández, Q. J. F. Enríquez, V. A. Gómez, J. E. Ortega y G. N. M. Maldonado (2011) Producción de forraje y composición morfológica del pasto Mulato (Brachiaria híbrido 36061) sometido a diferentes regímenes de pastoreo. Revista Mexicana de Ciencias Pecuarias 2 (4): 429-443.

http://www.redalyc.org/articulo.oa?id=265620968007

Da Silva S. C. y A. Hernández-Garay (2010) Manejo de pastoreo en praderas tropicales. Forrajes y su impacto en el Trópico. 1era (ed). México. Universidad Autónoma de Chiapas, México p. 4362.

Da Silva S. C. do J. D. D. Nascimento (2007) Avanços na pesquisa com plantas forrageiras tropicais em pastagens: características morfofisiológicas e manejo do pastejo. Revista Brasileira de Zootecnia 36: 122-138.

http://www.scielo.br/pdf/rbz/v36s0/14.pdf

Federick J. R. and P. J. Bauer (1999) "Physiological and Numerical Components of Wheat Yield", in Satorre HE. y GA. Slafer (eds). Wheat, Ecology and Physiology of Yield Determination. Foot Products Press, Nueva York.

García E. (2004) Modificaciones al Sistema de Clasificación Climática de Koppen. 4 (ed). Universidad Nacional Autónoma de México. México, D. F. 217 p.

Hernández G. A., H. P. A. Martínez, E. J. Zaragoza, H. H. Vaquera, G. H. F. Osnaya, T. B. M. Joaquín y Z. M. E. Velasco (2012)Caracterización del rendimiento de forraje de una pradera de alfalfa-ovillo al variar la frecuencia e intensidad de pastoreo. Revista Fitotecnia Mexicana 35 (3): 259-266.

http://www.scielo.org.mx/pdf/rfm/v35n3/v35n3a9.pdf

Horrocks R. and J. F. Vallentine (1999) Harvested Forages. Academic Press. Oval Road, London, United States of America p. 426.

Juskiw P. E., J. H. Helm and D. F. Salmon (2000) Postheading biomass distribution for monocrops and mixtures of small grain cereals. Crop Science 40 (1): 148-158.

Lara P., M. Canché, H. Magaña, E. Aguilar y J. Sanginés (2009) Producción de gas in vitro y cinética de degradación de harina de forraje de morera (Morus alba) mezclada con maíz. Revista Cubana de Ciencia Agrícola 43 (3): 273-279.

http://www.redalyc.org/pdf/1930/193015481010.pdf

Mattera J.; L. A. Romero, A. L. Cuatrin, P. S. Cornaglia and A. A. Grimoldi (2013) Yield components, light interception and radiation use efficiency of lucerne (Medicago sativa $\mathrm{L}$.) in response to row spacing. European Journal of Agronomy 45: 87-95. DOI: 10.1016/j.eja.2012.10.008 
Maldonado P. M. A., G. A. R. Rojas, S. P. Sánchez, L. M. B. Bottini, S. N. Torres, R. J. Ventura, C. S. Joaquín y G. M. J Luna (2019) Análisis de crecimiento del pasto Cuba OM-22 (Pennisetum purpureum X Pennisetum glaucum) en el trópico seco. Agroproductividad 12 (8): 17-22. http://revista-agroproductividad.org/index.php/agroproductividad/article/view/1445/1175

McKenzie B. A., P. D. Kemp, D. J. Moot, C. Matthew and R. J. Lucas (1999) Environmental effects on plant growth and development. In: White J, Hodgson J editors. New Zealand Pasture Crop Science. Auckland, N. Z: Oxford University Press p. 29-44.

Pérez B. M. T., A. Hernández-Garay, P. J. Pérez, H. J. G. Herrera y G. R. Bárcena (2002) Respuesta productiva y dinámica de rebrote del pasto ballico perenne a diferentes alturas de corte. Técnica Pecuaria México 40 (3): 251-263.

http://www.redalyc.org/pdf/613/61340307.pdf

Rojas G. A. R., S. N. Torres, P. M. A. Maldonado, S. P. Sánchez, B. A. García, P. S. I. Mendoza, V. P. Álvarez, P. J. Herrera y G. A. Hernández (2018) Curva de crecimiento y calidad del pasto cobra (Brachiaria Hibrido BR02/1794) a dos intensidades de cortes. Agroproductividad 11 (5): 34-38.

http://revista-agroproductividad.org/index.php/agroproductividad/article/view/368/256

Rojas G. A. R., G. A. Hernández, C. A. R. Quero, R. J. D. Guerrero, W. Ayala, R. J. L. Zaragoza y L. C. Trejo (2016) Persistencia de Dactylis glomerata L. solo y asociado con Lolium perenne L. y Trifolium repens L. Revista Mexicana de Ciencias Agrícolas 7(4): 885-895. http://www.scielo.org.mx/pdf/remexca/v7n4/2007-0934-remexca-7-04-00885.pdf

Rueda J. A., J. E. Ortega, G. A, Hernández, Q. J. F. Enríquez, R. J. D. Guerrero and C. A. R. Quero (2016)Growth, yield, fiber content and lodging resistance in eight varieties of Cenchrus purpureus (Schumach.) Morrone intended as energy crop. Biomass and Bioenergy 88: 59-65. https://doi.org/10.1016/j.biombioe.2016.03.007Get rights and content SAS (2011) The SAS 9.2 for Windows. SAS Institute Inc. Cary, North Carolina. USA.

Sevilla G. A., A. Pasinato y J. M. García (2001) Curvas de crecimiento de forrajeras templadas irrigadas. Archives of Latin America Animal Production 9: 91-98.

Velasco Z. M. E., A. Hernández-Garay y H. V. A. González (2005) Rendimiento y valor nutritivo del Ballico Perenne (Lolium perenne L.) en respuesta a la frecuencia de corte. Técnica Pecuaria en México 43 (2): 247-258.

http://www.redalyc.org/pdf/613/61343211.pdf

Velasco Z. M. E., G. A. Hernández, H. V. A. Gonzales, P. J. Pérez, H. H. Vaquera y S. A. Galvis (2001)Curva de crecimiento y acumulación de estacional del pasto ovillo (Dactylis glomerata L.). Técnica Pecuaria en México 39 (1): 14.https://cienciaspecuarias.inifap.gob.mx/index.php/Pecuarias/article/view/1338/1333

Wilson G. C. Y., G. A. Hernández, C. M. E. Ortega, C. C. López, G. R. Bárcena, R. J. L. Zaragoza y O. G. Aranda (2017) Análisis del crecimiento de tres líneas de cebada para producción de forraje, en el valle de México. Revista de la Facultad de Ciencias Agrarias UNCuyo 49 (2): 79-92.http://bdigital.uncu.edu.ar/objetos_digitales/9635/20172-cp06-wilsongarcia.pdf 